\title{
EFFECTS OF THE TEMPERATURE ON THE PORE EVOLUTION DURING SINTERING OF THE BELITE-SULFOALUMINATE CEMENT CLINKER USING X-RAY COMPUTED MICROTOMOGRAPHY
}

\author{
RAZVOJ POR MED SINTRANJEM \\ BELITNO-SULFOALUMINATNEGA CEMENTNEGA KLINKERJA Z \\ RENTGENSKO RAČUNALNIŠKO MIKROTOMOGRAFIJO
}

\author{
Sabina Dolenec ${ }^{1 *}$, Lidija Korat ${ }^{1}$, Maruša Borštnar ${ }^{1}$, Andrej Ipavec ${ }^{2}$, Lea Žibret ${ }^{1}$ \\ ${ }^{1}$ Slovenian National Building and Civil Engineering Institute, Dimičeva Steet 12, 1000 Ljubljana, Slovenia \\ ${ }^{2}$ Salonit Anhovo, d.d., Anhovo 1, 5210 Deskle, Slovenia
}

Prejem rokopisa - received: 2020-02-12; sprejem za objavo - accepted for publication: 2020-05-02

doi: $10.17222 /$ mit.2020.031

\begin{abstract}
In this paper, the effects of the sintering temperature on the pore evolution of the belite-sulfoaluminate cement clinker were evaluated. Belite-sulfoaluminate cement clinker with a targeted composition of $65 w / \% \beta$-belite, 20 w/\% calcium sulfoaluminate and $10 \mathrm{w} / \%$ ferrite was sintered at three different temperatures: $1200{ }^{\circ} \mathrm{C}, 1250{ }^{\circ} \mathrm{C}$ and $1300{ }^{\circ} \mathrm{C}$. To quantitatively evaluate the pore evolution during sintering, a 3D microstructure reconstruction by micro-CT was used. From the data, the pore volume fraction and pore number were extracted and compared, and the pore size distribution with the sintering temperature was obtained as well. Additionally, the pore shape and distribution were displayed in 3D based on actual microstructure data. Clinker samples were also characterized by $\mathrm{Hg}$-intrusion porosimetry and gas sorption. The changes in the pore evolution occurred to a larger extent when sintering at $1300{ }^{\circ} \mathrm{C}$. Apart from a significant porosity decrease, pore coarsening was evident at this temperature, reducing their connectivity and shrinkage of the clinker. Simultaneously, the bulk and apparent densities increased with the temperature due to densification, while the BET surface area of the studied clinkers decreased, indicating the rounding of pores and particle coalescence with an increasing grain growth.
\end{abstract}

Keywords: clinker, belite-sulfoaluminate, pore evolution, sintering, $\mu$-CT

Prispevek obravnava vpliv temperature sintranja na razvoj por pri belitno-sulfoaluminatnem cementnem klinkerju. Klinker z želeno sestavo faz $65 \mathrm{w} / \% \beta$-belita, $20 \mathrm{w} / \%$ kalcijevega sulfoaluminata in $10 \mathrm{w} / \%$ ferita je bil sintran pri treh različnih temperaturah: $1200{ }^{\circ} \mathrm{C}, 1250^{\circ} \mathrm{C}$ in $1300{ }^{\circ} \mathrm{C}$. Z računalniško mikrotomografijo smo na podlagi $3 \mathrm{D}$ rekonstrukcije mikrostrukture kvantitativno ocenili razvoj por pri sintranju. Iz podatkov smo pridobili delež volumna por in število por ter tudi porazdelitev por. Poleg tega je bila v 3D prikazana tudi oblika in porazdelitev por. Vzorci klinkerja so bili okarakterizirani tudi z živosrebrovo porozimetrijo in plinsko sorpcijo. Rezultati kažejo, da so se največje spremembe pri razvoju por zgodile pri sintranju na $1300{ }^{\circ} \mathrm{C}$. Poleg občutnega zmanjšanja poroznosti je bilo pri tej temperaturi opaziti tudi večanje por, zmanjševanje povezanosti med njimi in krčenje klinkerja. Obenem sta se volumska in navidezna gostota s temperaturo povečali zaradi zgoščevanja, medtem ko se je specifična površina BET klinkerjev zmanjšala, kar kaže na zaobljevanje por in povečevanje zrn.

Ključne besede: klinker, belit-sulfoaluminat, razvoj por, sintranje, $\mu$-CT

\section{INTRODUCTION}

The mechanisms of clinker formation are very complex, especially due to the many constituents and phases present in the process, as well as the mineralogical and physical changes that occur simultaneously. ${ }^{1}$ Clinkerization comprises solid-state reactions, solid-liquid and/or liquid-state reactions, polymorphic transformation on heating, and polymorphic stabilisation and crystallization upon cooling. ${ }^{2,3}$ Depending on the reaction conditions and variables such as the maximum heating temperature, the rate of temperature increase, retention time, the rate of cooling, the composition of the gaseous atmosphere and the chemical composition of kiln raw meal mixture, ${ }^{4}$ a significant variety of phases, as well as the relative pro-

*Corresponding author's e-mail:

sabina.dolenec@zag.si (Sabina Dolenec) portions can be formed, which will have an effect on the clinker and consequently also on the properties of the resulting cement and concrete. Furthermore, during sintering the density, shape, size and distribution of the pores change. ${ }^{5}$ Pores play an important role in sintering densification, whereby interparticle pores in particulate materials are eliminated by atomic diffusion at high temperatures. ${ }^{6,7}$ Porosity influences the sintered properties ${ }^{8}$ and is also one of the factors, as well as other microstructural factors (i.e., the crystal size, morphology, distribution and content of individual clinker phases, or presence of trace elements) that affect the grindability of cement clinker and consequently determines the economy of cement production. ${ }^{9-11}$ Namely, the initial grindability was found to be determined by porosity ${ }^{12}$ and it increased by hard burning and high melt content since they result in a clinker with a low porosity. ${ }^{9}$ 
S. DOLENEC et al.: EFFECTS OF THE TEMPERATURE ON THE PORE EVOLUTION DURING SINTERING ...

Table 1: Mass change and dimensional behavior of the cement clinker during sintering at different temperatures

\begin{tabular}{|c|c|c|c|c|c|c|}
\hline Sintering $(\mathrm{T})$ & $\begin{array}{l}\text { Weight } \\
\text { (g) }\end{array}$ & $\begin{array}{l}\text { Diameter } \\
(\mathrm{mm})\end{array}$ & $\begin{array}{l}\text { Height } \\
(\mathrm{mm})\end{array}$ & $\begin{array}{c}\text { Mass change } \\
(\%)\end{array}$ & $\begin{array}{c}\text { Radial change } \\
(\%)\end{array}$ & $\begin{array}{c}\text { Axial change } \\
(\%)\end{array}$ \\
\hline Non-sintered sample & 15.00 & 30.04 & 13.07 & & & \\
\hline $1200^{\circ} \mathrm{C}$ & 9.62 & 30.70 & 13.44 & -35.86 & +2.20 & +2.83 \\
\hline $1250^{\circ} \mathrm{C}$ & 9.83 & 24.14 & 11.69 & -34.47 & -19.64 & -10.56 \\
\hline $1300^{\circ} \mathrm{C}$ & 9.85 & 22.90 & 9.70 & -34.33 & -23.77 & -25.78 \\
\hline
\end{tabular}

While the clinkerization of conventional Ordinary Portland Cement clinkers has been extensively investigated over previous decades, there is only a limited number of studies discussing the clinkerization processes of belite-sulfoaluminate cement clinkers in detail. ${ }^{13-17}$ The cement based on those clinkers is considered to be low- $\mathrm{CO}_{2}$ and low-energy cement due to the lower energy use, lower $\mathrm{CO}_{2}$ emissions (20-30\% reduction compared to OPC) and consumption of by-products as raw materials. ${ }^{13,15,18,19}$ The main mineral analogues in this clinker are larnite (belite, $\mathrm{C}_{2} \mathrm{~S}$ ) and sodalite-type ye'elemite $\left(\mathrm{C}_{4} \mathrm{~A}_{3} \mathrm{~S}\right)$, also called Klein's salt tetracalcium aluminate sulphate or calcium sulfoaluminate. It may also contain other minor phases, such as brownmillerite-type ferrite $\left(\mathrm{C}_{4} \mathrm{AF}\right)$, mayenite $\left(\mathrm{C}_{12} \mathrm{~A}_{7}\right)$, gehlenite $\left(\mathrm{C}_{2} \mathrm{AS}\right)$, perovskite $(\mathrm{CT})$, periclase $(\mathrm{M})$ and excess anhydrite $(\mathrm{CS})$. $^{13,16,19-21}$ Such clinkers are generally produced by burning raw materials like limestone, clay and bauxite in addition to calcium sulphate, within a temperature range of $1200{ }^{\circ} \mathrm{C}$ to $1350{ }^{\circ} \mathrm{C} .{ }^{18,22}$ However, several industrial by-products are considered as substitutes for natural raw materials, e.g., coal fly ash, slag, red mud, phosphogypsum, flue gas desulfurization (FGD) gypsum, etc. ${ }^{15,23}$

Various approaches are possible in the investigation of porosity and a pore network of materials, but most of them do not give any information on the dimensional distribution of the pore structure components. Conventionally, the materials characterisation is performed in 2D, using scanning electron microscopy (SEM), while data acquired by $\mathrm{Hg}$-intrusion porosimetry (MIP) only give quantitative information on the pore structure, and they are inadequate to know the dimensional distribution of the pores, and their connectivity. ${ }^{24}$ In addition, MIP cannot detect closed porosity, and due to the ink-bottle effect it overestimates the smaller pore population. ${ }^{25}$ Furthermore, the sample preparation processes in these testing methods such as polishing, drying and especially the high pressure employed by the MIP method can often damage the microstructure of the samples before or during the analysis. ${ }^{26,27} 3 \mathrm{D}$ pore-scale imaging methods, like high-resolution X-ray computed tomography are now widely used to image and reconstruct 3D images of materials with a resolution on the micrometre-to-nanometre scale. ${ }^{26,28-30}$ Clearly, X-ray computed tomography is a powerful non-destructive test method for porosity and defect analysis of various materials, providing basic information on average porosity and pore size distribution, as well as information on pore connectivity or pore shapes through complex 3D analyses. ${ }^{31}$

In this paper, belite-sulfoaluminate cement clinker with a targeted composition of $65 w / \% \quad \beta-\mathrm{C}_{2} \mathrm{~S}, 20 w / \%$ $\mathrm{C}_{4} \mathrm{~A}_{3} \mathrm{~S}, 10 w / \% \mathrm{C}_{4} \mathrm{AF}$ was sintered at three different temperatures: $1200{ }^{\circ} \mathrm{C}, 1250{ }^{\circ} \mathrm{C}$ and $1300{ }^{\circ} \mathrm{C}$. 3D microstructure images reconstructed by $\mu$-CT together with the results of $\mathrm{Hg}$-intrusion porosimetry and gas sorption are used to understand the evolution of pores and pore networks. Pore fraction volume, pore number, pore size and distribution, and density were measured. The correlations of these parameters with the sintering process were discussed.

\section{EXPERIMENTAL PART}

\subsection{Materials}

Cement clinker having the nominal phase composition $65 w / \% \beta-\mathrm{C}_{2} \mathrm{~S}, 20 w / \% \mathrm{C}_{4} \mathrm{~A}_{3} \mathrm{~S}, 10 w / \% \mathrm{C}_{4} \mathrm{AF}$ was synthesised for the study. ${ }^{32}$ The clinker was prepared with ratios of limestone, flysch, bauxite, white titanogypsum and bottom ash from a coal thermal power plant (smaller quantities of mill scale were used for correction). The materials were proportioned by adapting the modified Bogue method. ${ }^{19}$

All the raw materials were first ground to pass through a $200-\mu \mathrm{m}$ sieve. The raw mixture $(200 \mathrm{~g})$ was then homogenized and ground for $3 \mathrm{~h}$ in $200 \mathrm{ml}$ of isopropanol using a ball mill (CAPCO Test Equipment Ball Mill Model 9VS). Pressed pellets were prepared us-

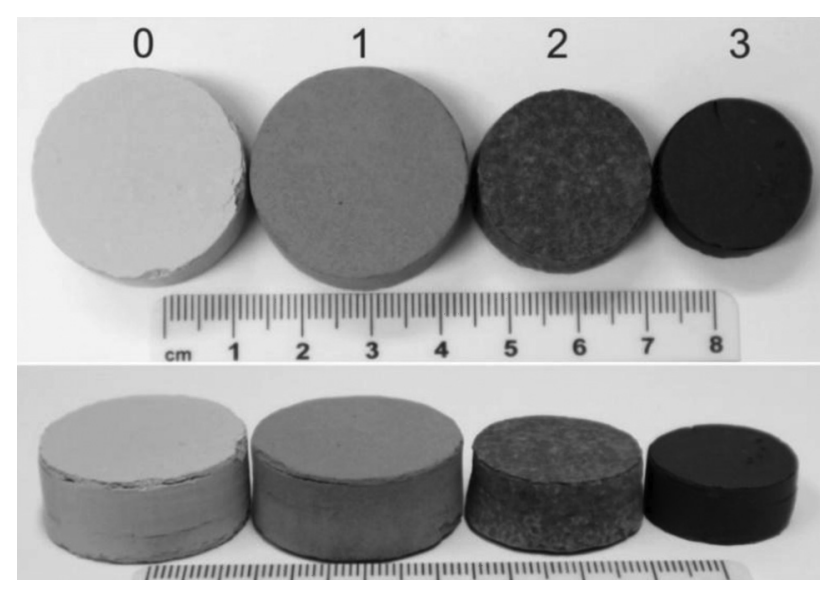

Figure 1: Macroscopic behaviour of the cement clinker. Sample 0: un-sintered compact; Sample 1: sintering at $1200{ }^{\circ} \mathrm{C}$; Sample 2: sintering at $1250{ }^{\circ} \mathrm{C}$, Sample 3 : sintering at $1300{ }^{\circ} \mathrm{C}$ 
ing a HPM $25 / 5$ press at $10.6 \mathrm{kN}$. For each pellet, with a diameter of $30 \mathrm{~mm}, 15 \mathrm{~g}$ of material was used.

The clinker mixtures were subjected to the following heating regimes: a) heating to $1200{ }^{\circ} \mathrm{C}, 1250{ }^{\circ} \mathrm{C}$ and $1300{ }^{\circ} \mathrm{C}$, b) heating rate of $10^{\circ} \mathrm{C} / \mathrm{min}, \mathrm{c}$ ) holding time at the final temperature for $60 \mathrm{~min}$, and d) natural cooling in a closed furnace. Figure 1 illustrates the macrographs of the cement clinker powder compacts before and after sintering. Table 1 provides mass and dimensional changes during sintering of the clinker compacts.

\subsection{Methods}

X-ray micro-computed tomography $(\mu-\mathrm{CT})$ was used to study the structural characteristics of the investigated samples, using an "Xradia $\mu$ CT-400" tomograph (Xradia, Concord, California, USA), set to $140 \mathrm{kV}$ and $71 \mu \mathrm{A}$. The specimens had a diameter of $7 \mathrm{~mm}$ and they were imaged using a CCD camera equipped with a $10 \times$ magnification optical objective and a resolution of $2 \mu \mathrm{m}$. A high-precision rotating stage was used, so that 1600 projection images were taken from different view-points with exposure times of $4 \mathrm{~s}$ per projection. In order to reconstruct the pore structure of the cement clinkers, as well as to determine their overall porosity and pore size distribution, Avizo Fire 3D-image analysis software was used, following the process for pore segmentation and quantification as described by Korat et al. ${ }^{29}$ The ROI (region of interest) box was determined from the centre of the sample, which had a size of $4 \mathrm{~mm}$. Image segmentation was performed (based on the voxel intensity histogram of the grayscale image), to determine the difference between the solid matrix and the air. A watershed algorithm was applied to the binary images in order to separate the pores step by step with a distance map. Once the separate pores have been identified, they can be labelled and further measured. Using a multiple labelling process, each pore can be identified in the label image, and assigned as unique index, mostly to get the volume, surface area, mean value etc. Such labelled images are displayed and quantified individually. Within this research, equivalent diameter and 3D volume (within Label Analysis module) were chosen.

The pore system of the cement clinker samples sintered at different temperatures was investigated by means of mercury intrusion porosimetry (MIP). Small representative fragments, approximately $1 \mathrm{~cm}^{3}$ in size, were dried in an oven for $24 \mathrm{~h}$ at $105^{\circ} \mathrm{C}$ and then analysed by Micromeritics®Autopore IV 9500 equipment
(Micromeritics, Norcross, GA, USA). The samples were analysed within the range of $0-414 \mathrm{MPa}$ using penetrometers for solid substrates. Two measurements were performed for each sintered clinker sample.

Nitrogen adsorption measurements were performed at $77 \mathrm{~K}$ using a Micromeritics ASAP-2020 analyser (Micromeritics, Norcross, GA, USA). The cement clinker samples were crushed into small pieces, approximately $0.5 \mathrm{~cm}^{3}$ in size. The mass of the analysed samples was $\approx 2 \mathrm{~g}$. The total specific surface area, the total pore volume and the pore-size distribution curves of the substrates were determined using the Brunauer-EmmetTeller (BET) method, t-plot analyses and the Barrett-Joyner-Halenda (BJH) method, respectively. ${ }^{33,34}$ The total pore volume and micropore volume of the samples were calculated using t-plot analysis. The BJH method was used to obtain pore size distribution curves. ${ }^{35}$ Two measurements were performed for each sintered clinker sample.

\section{RESULTS AND DISCUSSION}

For the sintered cement clinker, the overall porosity, determined by $\mu-\mathrm{CT}$, slightly increased from $5.56 \mathrm{a} / \%$ $1200{ }^{\circ} \mathrm{C}$ to $6.32 \mathrm{a} / \% 1250{ }^{\circ} \mathrm{C}$. Considering the sample sintered at $1300{ }^{\circ} \mathrm{C}$, a decrease in total porosity to $3.28 \%$ was observed. As seen from the MIP results in Table 2, the trend in porosity evolution during sintering is consistent with the $\mu$-CT data, although with noticeable differences in absolute values, specifically because MIP covers a pore size range from $0.0055 \mu \mathrm{m}(5.5 \mathrm{~nm})$ to $360 \mu \mathrm{m}$ and $\mu-\mathrm{CT}$ a pore size range above $1 \mu \mathrm{m}$. Moreover, the MIP would detect open pores only, so that the results would not be representative for the determination of closed pores.

Thus, the open porosity of the clinker sintered at $1250{ }^{\circ} \mathrm{C}$, determined by MIP, was increased to $39.0 \%$ compared to $33.4 \%$ of the $1200{ }^{\circ} \mathrm{C}$ sample. After that, the open porosity significantly decreased to $9.6 \%$ at $1300{ }^{\circ} \mathrm{C}$. In the early stages, the necks forming at the points of particle contacts have only small cross-sectional areas and particle rearrangements can take place during solid-state sintering, resulting in the local opening of large pores and the breaking of some contacts that are related to porosity growth. ${ }^{36}$ The increase in porosity from $1200{ }^{\circ} \mathrm{C}$ to $1250{ }^{\circ} \mathrm{C}$ could also indicate that the pore formation was dominated by the thermal explosion reaction, ${ }^{37}$ resulting in the deformation of the $1250{ }^{\circ} \mathrm{C}$

Table 2: Porosity, average pore diameter, bulk density, and apparent density of the sintered cement clinker samples, as determined by $\mathrm{Hg}$-porosimetry

\begin{tabular}{|c|c|c|c|c|c|}
\hline & Porosity $(\%)$ & $\begin{array}{c}\text { Average pore } \\
\text { diameter }(\mu \mathrm{m})\end{array}$ & $\begin{array}{c}\text { Median pore diameter } \\
\text { by volume }(\mu \mathrm{m})\end{array}$ & $\begin{array}{c}\text { Bulk density } \\
(\mathrm{g} / \mathrm{mL})\end{array}$ & $\begin{array}{c}\text { Apparent density } \\
(\mathrm{g} / \mathrm{mL})\end{array}$ \\
\hline $1200{ }^{\circ} \mathrm{C}$ & $33.4 \pm 0.7$ & $5.36 \pm 0.13$ & $5.06 \pm 0.08$ & $1.00 \pm 0.01$ & $1.50 \pm 0.04$ \\
\hline $1250^{\circ} \mathrm{C}$ & $39.0 \pm 0.1$ & $3.49 \pm 0.14$ & $4.05 \pm 0.03$ & $1.82 \pm 0.02$ & $2.98 \pm 0.03$ \\
\hline $1300^{\circ} \mathrm{C}$ & $9.6 \pm 0.4$ & $0.02 \pm 0.01$ & $0.42 \pm 0.55$ & $2.72 \pm 0.04$ & $3.01 \pm 0.02$ \\
\hline
\end{tabular}



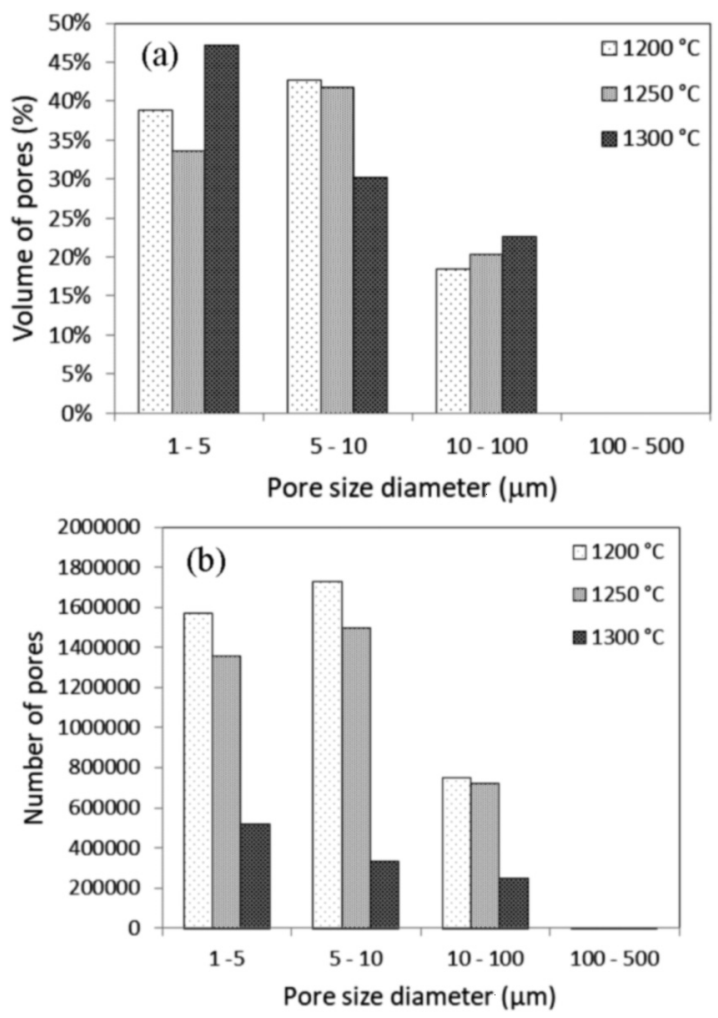

Figure 2: Pore size distribution determined by the means of $\mu$-CT for the samples, presented as: a) the volume of pores with regard to pore size diameter and b) as the number of pores with regard to pore size diameter

clinker (Figure 1). Pore coarsening leads to a reduced gas pressure in the pores resulting in a porosity increase. ${ }^{8}$ Namely, in the regime of high temperature $\left(\geq 1200{ }^{\circ} \mathrm{C}\right)$, calcium sulfate is chemically unstable and provokes the release of $\mathrm{SO}_{2}{ }^{38}$ On the other hand, the reduction of the total accessible porosity of the sample sintered at $1300{ }^{\circ} \mathrm{C}$ is due to the densification of the microstructure leading to a drop in connectivity between the pore spaces, resulting in a reduction of open pores, i.e., channel closure. ${ }^{36}$ Reduction of porosity could also be explained by the formation of a liquid phase, accompanied by the shrinkage of the compact due to the dissolving of particles, decreasing of distances between the centres of solid-phase particles, and melt penetrating into the interparticle pores. ${ }^{39}$ At temperatures up to $1250{ }^{\circ} \mathrm{C}$, solid-state reactions occur, while at higher temperatures, a liquid phase is formed. ${ }^{3}$ Most of the belite phase as well as the ferrite phase formation occur below around $1250{ }^{\circ} \mathrm{C}$ via solid-solid interactions. ${ }^{3}$ In general, belite is the first stable product to be formed at temperatures between $1000{ }^{\circ} \mathrm{C}$ and $1200{ }^{\circ} \mathrm{C} .{ }^{40}$ Between $1100{ }^{\circ} \mathrm{C}$ and $1200{ }^{\circ} \mathrm{C}$, the ferrite phase forms. ${ }^{41}$ Calcium sulfoaluminate is formed at $900-1000{ }^{\circ} \mathrm{C}$, which increases with the increasing temperature, peaking at $1300-1350{ }^{\circ} \mathrm{C} .{ }^{38}$ Moreover, the decrease in porosity could indicate an increase of the grain size, as an inverse relationship between grain size and fractional porosity during sintering has been reported. ${ }^{42}$

The reduction of pore volume results in shrinkage of the sintered clinkers (Figure 1, Table 1). While the mass does not change significantly with the sintering temperature, the radial and axial shrinkage was obvious at sintering above $1200{ }^{\circ} \mathrm{C}$. Furthermore, it was noted that the shrinkage increased sharply with increasing tempera-

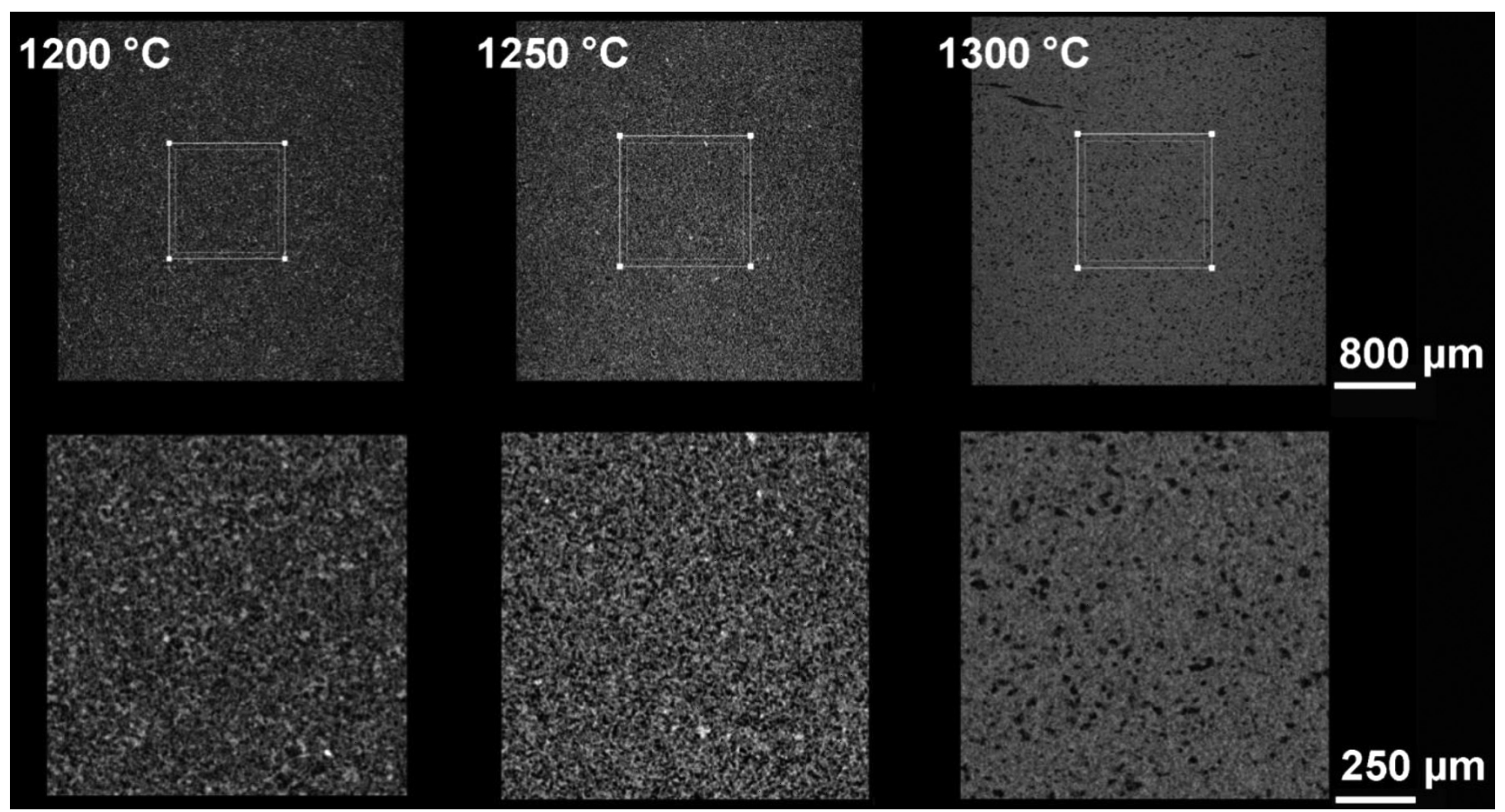

Figure 3: 2D images (XZ view) of samples sintered at $1200{ }^{\circ} \mathrm{C}, 1250{ }^{\circ} \mathrm{C}$ and $1300{ }^{\circ} \mathrm{C}$ with enlarged bottom figures regarding FOV (field of view) 
ture, where a radial shrinkage of $23.77 \%$ and an axial shrinkage of $25.78 \%$ were reached at $1300{ }^{\circ} \mathrm{C}$.

With sintering temperature, differences also occur in pore-size distribution as indicated by $\mu$-CT, MIP and gas sorption.

The pore size distribution of the clinkers extracted from $\mu$-CT data (Figure 2a) showed that the clinker sample sintered at $1300{ }^{\circ} \mathrm{C}$ had the largest volume of larger pores $(10-100 \mu \mathrm{m})$ as well as smaller pores $(1-5 \mu \mathrm{m})$. On the other hand, the volume of pores in the range of 5-10 $\mu \mathrm{m}$ was smaller compared to the samples sintered at $1200{ }^{\circ} \mathrm{C}$ and $1250{ }^{\circ} \mathrm{C}$. The volume of pores larger than $100 \mu \mathrm{m}$ was almost negligible with all three sintering temperatures. The change in pore size distribution was smaller when comparing samples sintered at $1200{ }^{\circ} \mathrm{C}$ and $1250{ }^{\circ} \mathrm{C}$ than samples sintered $1250{ }^{\circ} \mathrm{C}$ and $1300{ }^{\circ} \mathrm{C}$, similar to the observations for the dimensional and porosity changes described above. However, a continuous increase of larger pores in the range $10-100 \mu \mathrm{m}$ with increasing temperature was obvious, which suggests the transition of the pores to isolated spherical pores. ${ }^{43}$ Furthermore, as seen from Figure $\mathbf{2} \mathbf{b}$, the number of pores, determined by $\mu$-CT was significantly smaller for the sample sintered at $1300{ }^{\circ} \mathrm{C}$. The pore size grows with sintering temperature, although a reduction in porosity occurs because of the elimination of pores from the system. ${ }^{44}$ Consequently, the coalescence of small pores significantly impedes the densification process, ${ }^{45}$ which can lead to a pore size distribution shift towards larger

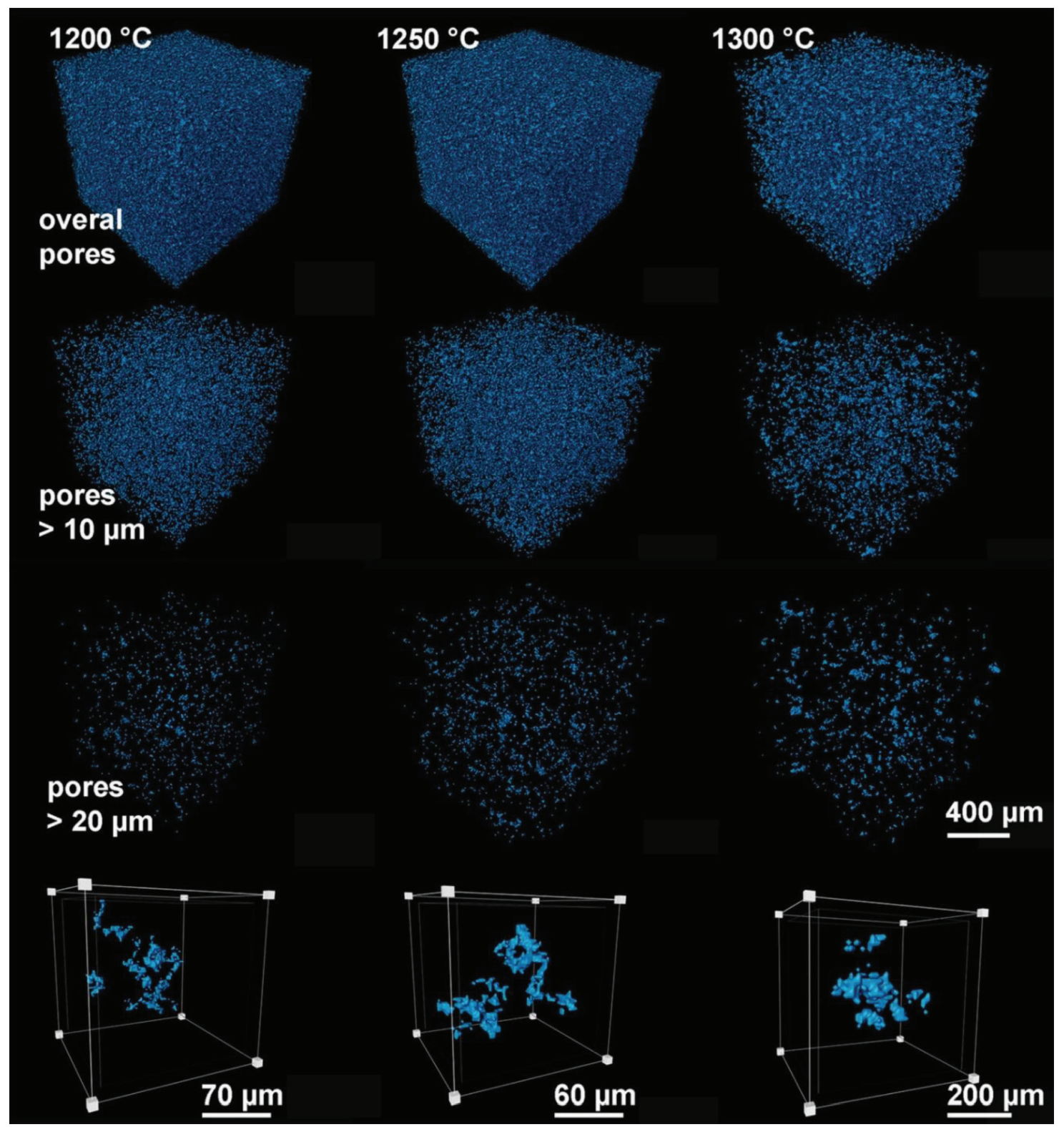

Figure 4: 3D-pore distribution of cement clinkers sintered at different temperatures with respect to different pore ranges. The region of interest being approximately $1 \mathrm{~mm}$ in size (presenting overall porosity) and $200 \mu \mathrm{m}$ in size (presenting connectivity/isolation of large pores on large scale), taken from the centre of the sample. 
sizes. ${ }^{46}$ Pores collapse into a closed condition during sintering in what is termed the final stage, and due to pressure balances they grow as porosity decreases. ${ }^{8}$ Apart from the larger pores, a shift to smaller pores with the enhanced temperature of sintering is obvious. At $1300{ }^{\circ} \mathrm{C}$, small pores formed and showed a shrinkage effect. ${ }^{37}$

From the results presented in Figure 3, it is seen that when clinker samples are sintered, pore growth effects the result in altered pore morphology. For a better visualisation, Figure 4 shows the 3D pore shape and pore distribution of the clinker samples, the region of interest being approximately $1 \mathrm{~mm}$ in size, taken from the centre of the sample. It is evident that at lower sintering temperatures, the pores are interconnected, while with continued sintering, pores become isolated and grow. Namely, only late in the sintering process do the channels close and isolated pores are formed that may grow or, in those rare cases where full density is achieved, shrinking to
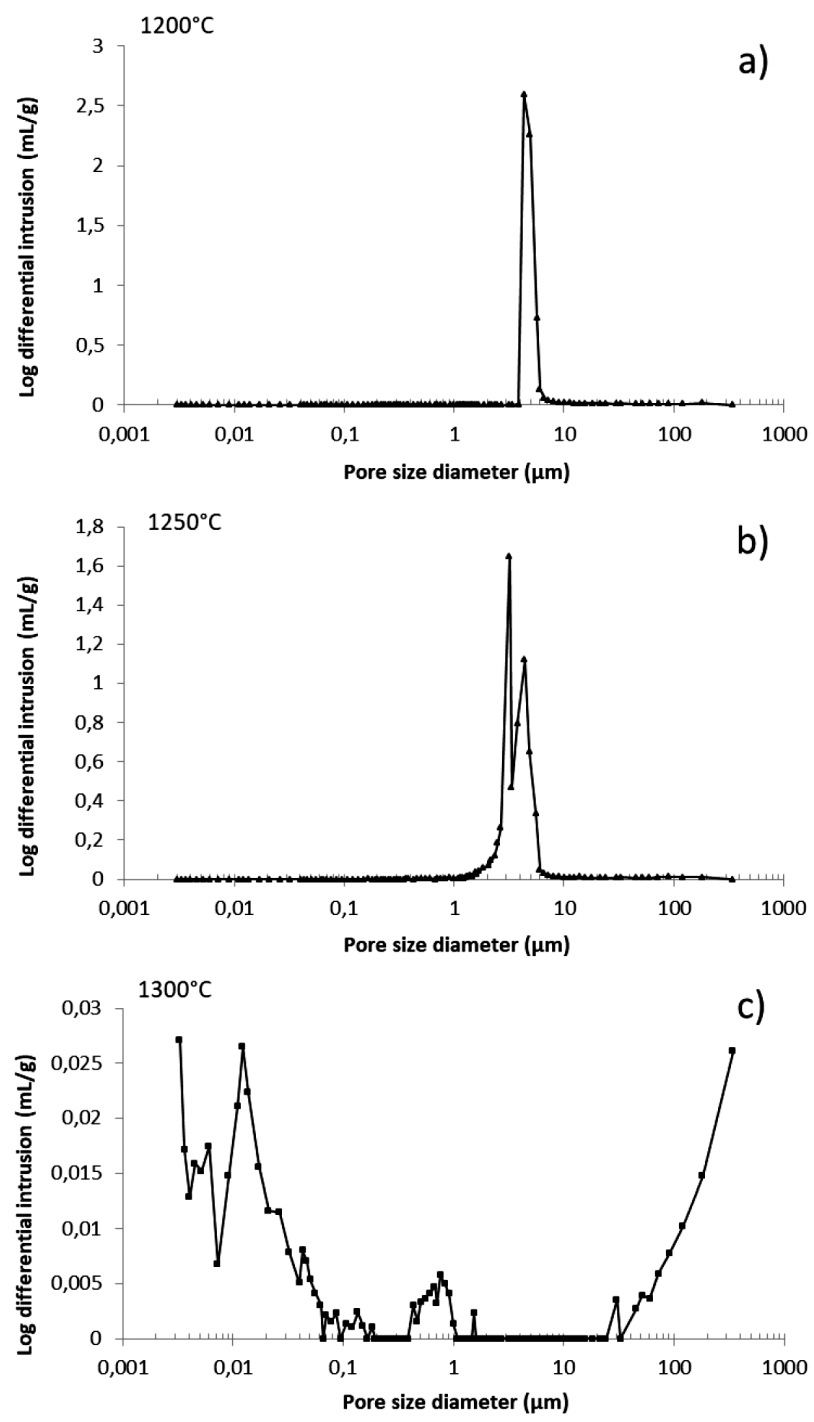

Figure 5: Log differential intrusion versus pore size of the samples zero. ${ }^{36}$ A visual examination of CT data, prepared by Avizo software, has shown that open pores are typically thin, elongated and irregularly shaped, while the closed pores are typically more equiaxed (Figure 4). When the samples are sintered at higher temperatures, the large amount of small isolated pores disappear and some pores merge with others to form large pores. ${ }^{7}$ As seen from Figure 4 (last row), pores are mostly isolated at $1300{ }^{\circ} \mathrm{C}$.

In regard to the results of the MIP (Figure 5), the pores of the samples sintered at $1200{ }^{\circ} \mathrm{C}$ and $1250{ }^{\circ} \mathrm{C}$ were unimodally distributed, with the largest intrusion being around $5 \mu \mathrm{m}$ and $3 \mu \mathrm{m}$, respectively, with a shift toward smaller pores with a higher temperature. A bimodal distribution of pores was characteristic of the sample sintered at $1300{ }^{\circ} \mathrm{C}$, with an intrusion peak at around $0.01 \mu \mathrm{m}$ and a larger intrusion peak at around $200 \mu \mathrm{m}$, yet again indicating a major change in the clinker microstructure that occurred during sintering at $1300{ }^{\circ} \mathrm{C}$. Both the average and median pore diameters decreased with the sintering temperature, while the difference between $1200{ }^{\circ} \mathrm{C}$ and $1250{ }^{\circ} \mathrm{C}$ was much smaller than between $1250{ }^{\circ} \mathrm{C}$ and $1300{ }^{\circ} \mathrm{C}$ (Table 2). Despite that the average pore diameter was smallest for the $1300{ }^{\circ} \mathrm{C}$ sample, from the pore size distribution it is clearly seen that the amount of larger pores increased in comparison to the samples sintered at lower temperatures. This could suggest pore shrinkage due to densification, simultaneous with pore coarsening. However, the fact that MIP only covers open pores should be considered.

Figure 6 shows that the amount of pores diminished with sintering temperature, supporting the results obtained by $\mu$-CT. In terms of pore-size distribution, sintering resulted in a decrease or increase in the per-

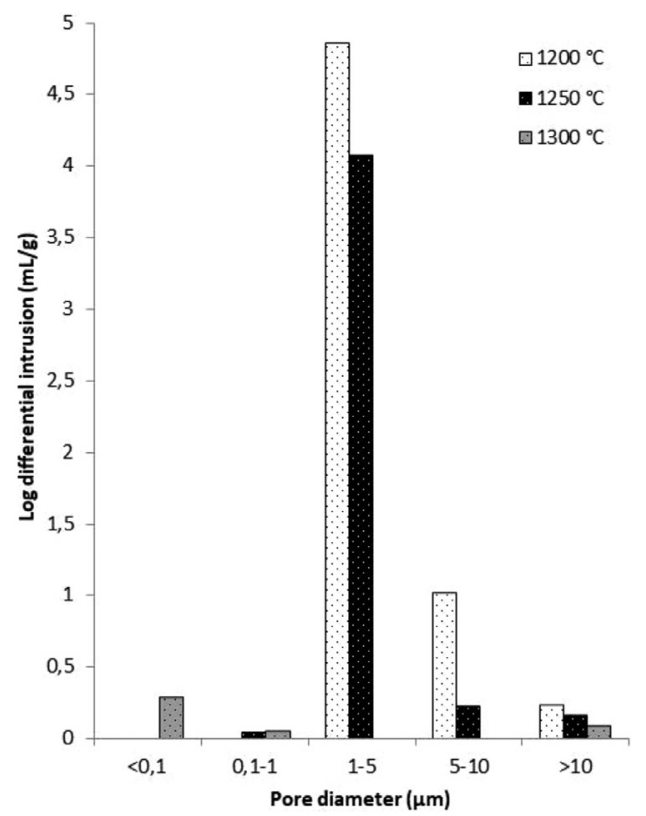

Figure 6: Pore-size distribution of the clinker samples based on the Hg-porosimetry data 

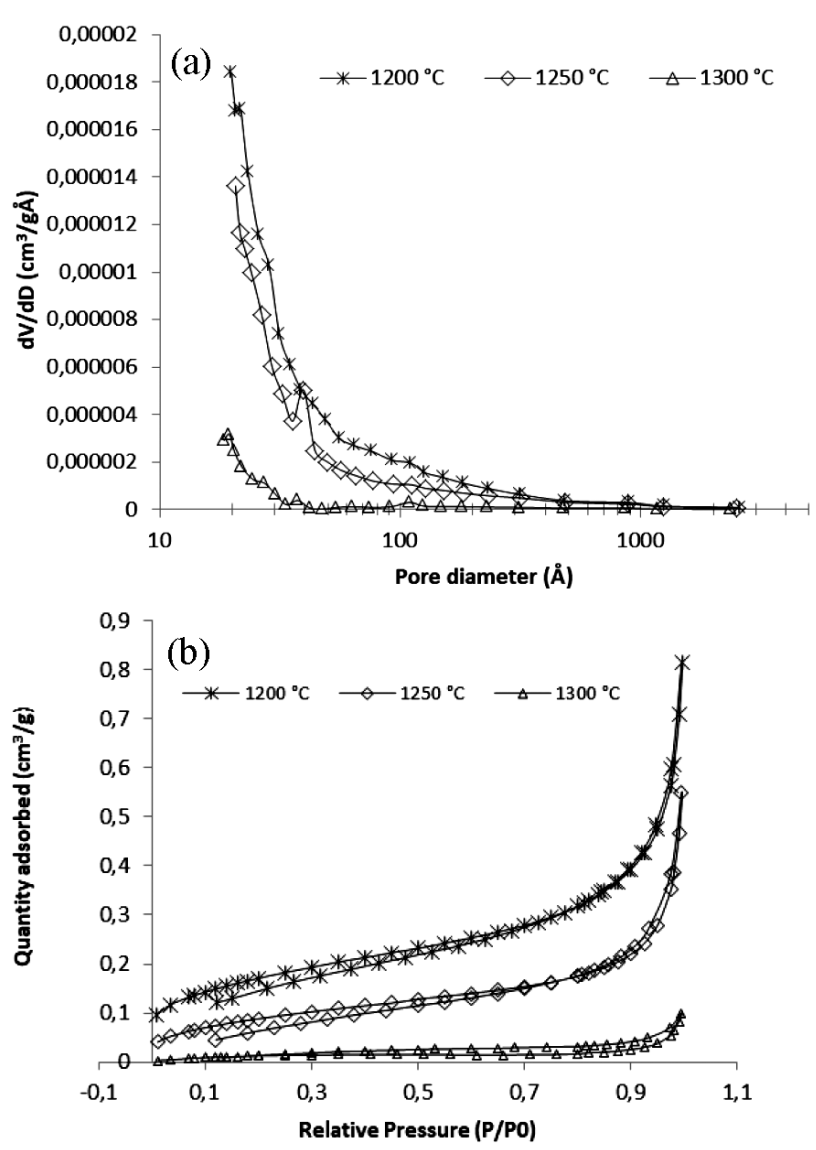

Figure 7: The results of $\mathrm{N}_{2}$ adsorption measurements: a) Pore-diameter logarithm differential distribution graph of clinker samples by nitrogen adsorption, b) The $\mathrm{N}_{2}$-physisorption isotherms for the samples investigated

centage of pores in certain size ranges, which is especially evident for the sample sintered at $1300{ }^{\circ} \mathrm{C}$.

As indicated by the nitrogen adsorption method samples sintered at all three temperatures had a similar, continuously increasing type of pore size distribution (Figure 7a), in which the overall trend was that the finer the pore diameter, the greater the volume of pores developed. Results showed a clear reduction in macropores

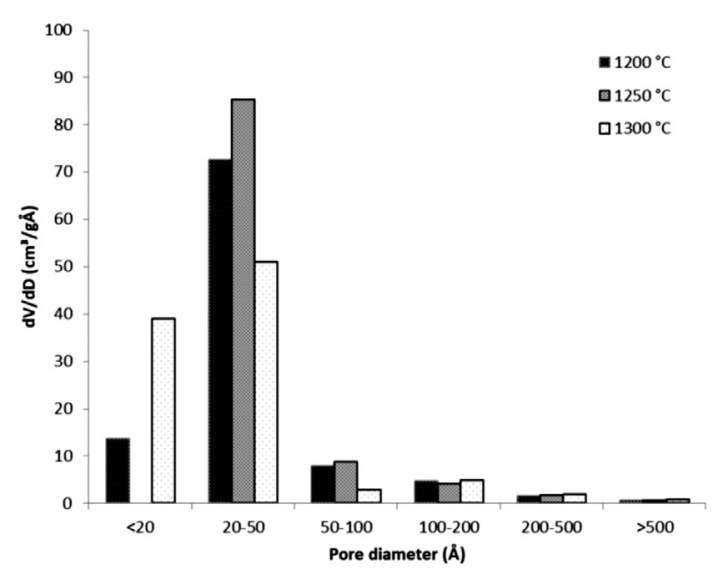

Figure 8: Pore-size distribution of the clinker samples based on the nitrogen-adsorption data $(r>50 \mathrm{~nm})$ and mesopores $(2 \mathrm{~nm}<r<50 \mathrm{~nm})$, since there was an increase in micropores $(r<2 \mathrm{~nm})$ for the sample sintered at $1300{ }^{\circ} \mathrm{C}$ (Figure 8). The volume of pores accessible to the gas decreased with the sintering temperature (Table 3, Figure 8), due to the densification process and the formation of a liquid phase. The average pore diameter of the sintered clinkers was in the range of $5.56 \mathrm{~nm}$ to $6.43 \mathrm{~nm}$ (Table 3). All of the samples studied had a Type-II physisorption isotherm (Figure 7b), which is characteristic of non-porous and macroporous materials with diameters exceeding micropores. ${ }^{47}$

Table 3: Results of the $\mathrm{N}_{2}$-adsorption measurements of the samples investigated

\begin{tabular}{|c|c|c|c|c|}
\hline $\begin{array}{c}\text { Sintering } \\
T /{ }^{\circ} \mathrm{C}\end{array}$ & $\begin{array}{c}\mathrm{BET} \text { surface } \\
\text { area } \\
\left(\mathrm{m}^{2} / \mathrm{g}\right)\end{array}$ & $\begin{array}{c}\text { Total pore } \\
\text { volume } \\
\left(\mathrm{cm}^{3} / \mathrm{g}\right)\end{array}$ & $\begin{array}{c}\text { Average } \\
\text { pore diame- } \\
\text { ter }(\mathrm{nm})\end{array}$ & $\begin{array}{c}\text { Micropore } \\
\text { volume } \\
\left(\mathrm{cm}^{3} / \mathrm{g}\right)\end{array}$ \\
\hline $1200{ }^{\circ} \mathrm{C}$ & $0.63 \pm 0.01$ & 0.000871 & $5.56 \pm 0.08$ & -0.000005 \\
\hline $1250{ }^{\circ} \mathrm{C}$ & $0.37 \pm 0.04$ & 0.000543 & $6.43 \pm 0.12$ & -0.000038 \\
\hline $1300{ }^{\circ} \mathrm{C}$ & $0.05 \pm 0.01$ & 0.000085 & $5.84 \pm 0.10$ & -0.000014 \\
\hline
\end{tabular}

Furthermore, both the bulk density and the apparent density show an upward tendency as the sintering temperature rises, which indicates the sample gradually undergoing densification (Table 2). The bulk density of the samples increased linearly with the sintering temperature, from $1.00 \mathrm{~g} / \mathrm{mL}$ at $1200{ }^{\circ} \mathrm{C}$ to $2.72 \mathrm{~g} / \mathrm{mL}$ at $1300{ }^{\circ} \mathrm{C}$ (Figure 9). As the bulk density of the clinkers increased, individual grains began to grow - coarsening the grains. On the other hand, apparent density, correlated with internal porosity, increased to the temperature of $1250{ }^{\circ} \mathrm{C}$, indicating the internal porosity constantly eliminating, but at $1300{ }^{\circ} \mathrm{C}$ it remained unchanged (Figure 9), which can be explained by the internal pores being nearly non-existent. ${ }^{48}$ Furthermore, pores require proximity to a grain boundary to shrink during sintering, while pores separated from grain boundaries remain stable and resist densification. Accordingly, grain growth is detrimental to the sintering since the grain boundaries become more widely spaced, have less proximity to pores, and often move faster than the pores. Rapid grain coarsening generates the conditions where sintering prematurely terminates with a considerable residual porosity. ${ }^{8}$ As the

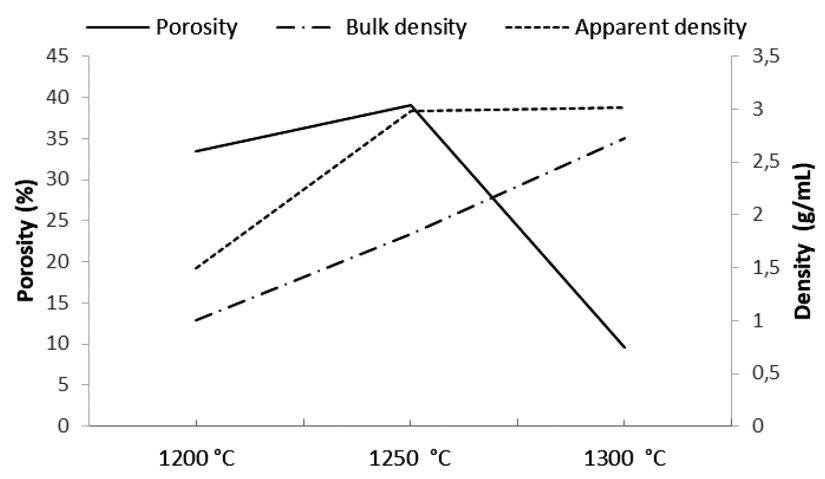

Figure 9: Porosity, bulk density and apparent density of clinker samples sintered at different temperatures 
clinker cools, the main liquid phase crystallizes to form phases. Since higher temperatures inflate the balloons due to the sulfate exhalation, leading to clinker swelling, pores near free surfaces disappear, but internal pores undergo coarsening. ${ }^{8}$ Consequently, the density increases during sintering with simultaneous pore growth instead of the expected pore shrinkage. On the other hand, the small pores that were interconnected or partly connected would develop into closed pores during the high-temperature sintering process, thus reducing the open porosity (ref. no. ${ }^{37}$ ). The pores are assumed to be interconnected at low densities, cylindrical at intermediate densities, and spherical at high densities. ${ }^{49,50}$

The values of the BET specific surface area decreased with the sintering temperature (Table 3). In addition to densification, this fact could also be due to two mechanisms, such as the rounding of pores (as evident from Figure 8) that decrease the surface area and particle coalescence with increasing grain growth (ref. no. ${ }^{5}$ ). Yet, many structural changes compatible with surface area reduction may occur, i.e., grain growth, pore shrinkage or growth, particle modification and variation in density (ref. no. ${ }^{5}$ ).

\section{CONCLUSIONS}

Pore evolution of belite-sulfoaluminate cement clinker during sintering at different temperatures was evaluated using $\mu \mathrm{CT}, \mathrm{Hg}$-porosimetry and gas sorption.

Larger changes in clinker microstructure were observed at $1250{ }^{\circ} \mathrm{C}$ to $1300{ }^{\circ} \mathrm{C}$ than at $1200{ }^{\circ} \mathrm{C}$ to $1250{ }^{\circ} \mathrm{C}$. The porosity of the clinkers increased when sintering from $1200{ }^{\circ} \mathrm{C}$ to $1250{ }^{\circ} \mathrm{C}$ and then diminished at $1300{ }^{\circ} \mathrm{C}$, which is attributed to pore coarsening and densification. Pores are interconnected at lower sintering temperatures, while pore isolating and the volume of larger pores increased with the sintering temperature due to pore coalescence, which was evident in $3 \mathrm{D}$ analysis using $\mu$-CT. Furthermore, with increasing temperature, the BET-specific surface was reduced, while the bulk and apparent densities increased, indicating densification of the clinker microstructure.

The evolution of the pores during clinker sintering can be useful in understanding how sintering parameters like temperature might influence the evolution of microstructure and hence macroscopic properties.

\section{Acknowledgment}

Project No. C3330-17-529035 "Raziskovalci2.0-ZAG-529035" was granted by the Ministry of Education, Science and Sport of the Republic of Slovenia. The investment is co-financed by the Republic of Slovenia, Ministry of Education, Science and Sport and the European Regional Development Fund. The authors acknowledge the financial support from the Slovenian Research Agency (research core funding No. P2-0273). The au- thors would also like to acknowledge Mr Andrej Kranjc for his help with $\mu$-CT data processing.

\section{REFERENCES}

${ }^{1}$ B. Hökfors, D. Boström, E: Viggh, R. Backman, On the phase chemistry of Portland cement clinker, Adv. Cem. Res ., 27 (2015) 1, 50-60, doi:10.1680/adcr.13.00071

${ }^{2}$ M. S. Idris, K. N. Ismail, S. B. Jamaludin, Comparative Characterization of Clinkers microstructure at different temperature zone during cement production, Am. J. Appl. Sci, 4, (2007) 8, 543-546, doi: 10.3844/ajassp.2007.543.546

${ }^{3}$ S. Telschow, F. Frandsen, K. Theisen, K. Dam-Johansen, Cement Formation-A Success Story in a Black Box: High Temperature Phase Formation of Portland Cement Clinker, Ind. Eng. Chem. Res., 51 (2012), 51, 10983-11004 doi:10.1021/ie300674j

${ }^{4}$ W. Kurdowski, Cement and Concrete Chemistry, Springer, New York 2014, 700 str.

${ }^{5}$ J. A. Varela, O. J. Whittemore, E. Longo, Pore size evolution during sintering of ceramic oxides, Ceram. Int., 16 (1990) 3, 177-189, doi:10.1016/0272-8842(90)90053-I

${ }^{6}$ P. L. Chen, I. W. Chen, Sintering of Fine Oxide Powders, 1. Microstructural Evolution, J. Am. Ceram. Soc., 79 (1996) 2, 3129-41, doi:10.1111/j.1151-2916.1996.tb08087.x

${ }^{7}$ Z. Hu, K. Lu, Evolution of Pores and Tortuosity During Sintering, J. Am. Ceram. Soc., 97 (2014) 8, 2383-2386, doi:10.1111/jace.13080

${ }^{8}$ R. M. German, Coarsening in Sintering: Grain Shape Distribution, Grain Size Distribution, and Grain Growth Kinetics in Solid-Pore Systems, Crit. Rev. Solid. State, 35 (2010) 4, 263-305, doi:10.1080/10408436.2010.525197

${ }^{9}$ G. C. Bye, Portland Cement: Composition, Production and Properties, 1983, 149. str.

${ }^{10}$ L. Hills, Clinker microstructure and grindability: updated literature review, SN2967, Portland cement assocation, Skokie, Illinois, USA, 2007, 15 str.

${ }^{11}$ B. Felekoğlu, K. Tosun, B. Baradan, A. Altun, Relationship between clinker porosity and interstitial phase morphology, Adv. Cem. Res., 20 (2008), 3, 109-119 doi:10.1680/adcr.2008.20.3.109

${ }^{12}$ L. M. Tavares, M. Cromwell Cerqueira, J. J. Less, Analysis of the grinding behaviour of various Portland cement clinkers, Materials science, 2009, https://www.zkg.de/en/artikel/zkg_Analysis_of_the_ grinding_behaviour_of_various_Portland_cement_clinkers_106412.html

${ }^{13}$ M. C. Martín-Sedeño, A. J. M. Cuberos, Á. G. De la Torre, G. Álvarez-Pinazo, L. M. Ordónez, M. Gateshki, M. A. G. Aranda, Aluminum-rich belite sulfoaluminate cements: Clinkering and early age hydration, Cem. Concr. Res., 40 (2010) 3, 359-369, doi:10.1016/ j.cemconres.2009.11.003

${ }^{14}$ B. Ma, X. Li, X. Shen, Y. Mao, H. Huang, Enhancing the addition of fly ash from thermal power plants in activated high belite sulfoaluminate cement, Constr. Build. Mater., 52 (2014), 261-266, doi:10.1016/j.conbuildmat.2013.10.099

${ }^{15}$ F. Bullerjahn, D. Schmitt, M. Ben Haha, Effect of raw mix design and of clinkering process on the formation and mineralogical composition of (ternesite) belite calcium sulphoaluminate ferrite clinker, Cem. Concr. Res., 59 (2014) 5, 87-95, doi:10.1016/j.cemconres. 2014.02.004

${ }^{16}$ A. G. De la Torre, A. J. M. Cuberos, G. Alvarez-Pinazo, A. Cuesta, M. A. G. Aranda, In situ powder diffraction study of belite sulfoaluminate clinkering, J. Synch. Rad., 18 (2011), 506-514, doi:10.1107/S0909049511005796

${ }^{17}$ G. Q. Liu, Q. Yang, L. Jiang, P. Xue, X. L. Zhang, F. L. Han, Sintering characteristics of BCSAF cement clinker with added wastes from production of manganese and magnesium metals, Adv. Cem. Res., 29 (2017) 6, 227-235, doi:10.1680/jadcr.16.00035 


\section{S. DOLENEC et al.: EFFECTS OF THE TEMPERATURE ON THE PORE EVOLUTION DURING SINTERING ...}

${ }^{18}$ K. Quillin, Performance of belite-sulfoaluminate cements, Cem Conc Res, 31 (2001), 1341-1349, doi:10.1016/S0008-8846(01) 00543-9

${ }^{19}$ I. A. Chen, M. C. G. Juenger, Synthesis and hydration of calcium sulfoaluminate belite cements with varied phase compositions, J. Mater. Sci., 46 (2011), 2568-2577, doi:10.1007/s10853-010-5109-9

${ }^{20}$ P. Arjunan, M. R. Silsbee, D. M. Roy, Sulfoaluminate-belite cement from low-calcium fly ash and sulfur-rich and other industrial by-products, Cem. Concr. Res., 29 (1999) 8, 1305-131, doi:10.1016/S0008-8846(99)00072-1

${ }^{21}$ G. Alvarez-Pinazo, I. Santacruz, L. León-Reina, M. A. G. Aranda, A. G. De la Torre, Hydration reactions and mechanical strength developments of iron-rich sulfobelite eco-cements, Ind. Eng. Chem. Res., 52 (2013) 47, 16606-16614, doi:10.1021/ie402484e

${ }^{22}$ B. Ma, X. Li, Y. Mao, X. D. Shen, Synthesis and characterization of high belitesulfoaluminate cement through rich alumina fly ash and desulfurization gypsum, Ceram. - Silik., 57 (2013) 1, 7-13

${ }^{23}$ N. Ukrainczyk, N. Frankovič Mihelj, J. Šipušič, Calcium Sulfoaliminate Eco-Cement from Industrial Waste, Chem. Biochem. Eng.Q., 27 (2013) 1, 83-93, http://hrcak. srce.hr/99441.

${ }^{24}$ R. Kumar, B. Bhattacharjee, Study on some factors affecting the results in the use of MIP method in concrete research, Cem. Concr. Res., 33 (2003) 3, 417-424. doi:10.1016/S0008-8846(02)00974-2

${ }^{25}$ S. Diamond, Mercury porosimetry: an in appropriate method for the measurement of pore size distributions in cement-based materials, Cem. Concr. Res., 30 (2000), 1517-1525, doi:10.1016/S00088846(00)00370-7

${ }^{26}$ L. Salvo, P. Cloetens , E. Maire, S. Zabler, J. Blandin, J.Buffiež\#re, W. Ludwig, E. Boller, D. Bellet, C. Josserond, X-ray micro-tomography an attractive characterisation technique in materials science, Nucl. Instrum. Methods Phys. Res. Sect. B, 200 (2003), 273-286, doi:10.1016/S0168-583X(02)01689-0

${ }^{27}$ Y. J. He, J. Mote, D. A. Lange, Characterization of microstructure evolution of cement paste by micro computed tomography, J. Cent South Univ, 20 (2013) 4, 1115-1121. doi:10.1007/s11771013-1592-x

${ }^{28}$ H. Tauda, T. R. Martinez-Angelesa, J. F. Parrotb, L. HernandezEscobedoa, Porosity estimation method by X-ray computed tomography, J. Petrol. Sci. Eng., 47 (2005) 3-4, 209-217, doi:10.1016/ j.petrol.2005.03.009

${ }^{29}$ L. Korat, V. Ducman, A. Legat, B. Mirtič, Characterisation of the pore-forming process in lightweight aggregate based on silica sludge by means of X-ray micro-tomography (micro-CT) and mercury intrusion porosimetry (MIP), Ceram. Int., 39 (2013) 6, 6997-7005, doi:10.1016/j.ceramint.2013.02.037

${ }^{30}$ N. Bossa, P. Chaurand, J. Vicente, D. Borschneck, C. Levard, O. Aguerre-Chariol, J. Rose, Micro- and nano-X-ray computed-tomography: A step forward in the characterization of the pore network of a leached cement paste, Cem. Concr. Res., 67 (2015), 138-147, doi:10.1016/j.cemconres.2014.08.007

${ }^{31}$ A. du Plessis, B. J. Olawuyi, W. P. Boshoff, S. G. le Roux, Simple and fast porosity analysis of concrete using X-ray computed tomography, Mater Struct 49, 553-562 (2016), doi:10.1617/s11527014-0519-9

${ }^{32}$ L. Žibret, A. Ipavec, S. Kramar, Microstructure of belite sulfoaluminate clinker and its influence on clinker reactivity, International Workshop on Calcium sulfoaluminate cements, Dübendorf 2018, 60 ${ }^{33}$ S. J. Gregg, K. S. W. Sing, Adsorption, surface area and porosity, $2^{\text {nd }}$ ed., Academic Press, London 1982, 303 str.
${ }^{34}$ R. W. Adamson, A. P. Gast, Physical chemistry of surfaces, $6^{\text {th }}$ ed., Wiley, New York 1997, Chapter 17, 808 str.

${ }^{35}$ E. P. Barrett, L. G. Joyner, P. P. Halenda, The determination of pore volume and area distributions in porous substances, I. Computations from nitrogen isotherms, J. Am. Chem. Soc., 73 (1951), 373-80, doi:10.1021/ja01151a046

${ }^{36}$ H. E. Exner, G. Petzow, A Critical Assessment of Porosity Coarsening during Solid state Sintering, Adv. Sci. Tech., 45 (2006), 539-548, doi:10.4028/www.scientific.net/AST.45.539

${ }^{37}$ X. Jiao, X. Wang, P. Feng et al., Microstructure Evolution and Pore Formation Mechanism of Porous TiAl3 Intermetallics via Reactive Sintering, Acta Metall. Sin. (Engl. Lett.) 31(2018), 440-448, doi:10.1007/s40195-017-0663-7

${ }^{38}$ G. Huiling, X. Junlin, Thermodynamics and Kinetics of Calcium Sulphoaluminate, Journal of Wuhan University of Technology-Mater. Sci. Ed., 2011, 2383-2386, doi:10.1111/jace.13080

${ }^{39}$ A. P. Savttskii, E. S. Kim, L. S. Martsunova, Compact shrinkage during liquid-phase sintering, Sov. Powder. Metall., 19 (1980), 593-596, doi: $10.1007 / \mathrm{BF} 00790545$

${ }^{40}$ Odler, I. (2000), Special Inorganic Cements, Taylor and Francis, London, 416

${ }^{41}$ K. J. D. Mackenzie, R. A. Fletcher, The formation of portland cement clinker under applied electric fields, I. Thermal reaction sequence and kinetics of clinker phase formation, Thermochim. Acta, 28 (1979) 1, 161-173, doi:10.1016/0040-6031(79)87015-X

${ }^{42}$ C. A. Bruch, Sintering kinetics for the high density alumina process, Ceram. Bull., 41 (1962), 799-806

${ }^{43}$ T. Fang, H. Palmour, Evolution of pore morphology in sintering powder compacts, Ceram. Int., 16 (1990) 1, 1-10, doi:10.1016/02728842(90)90056-L

${ }^{44}$ D. Sen, T. Mahata, A. K. Patra, S. Mazumder, B. P. Sharma, Effect of Sintering Temperature on Pore Growth in $\mathrm{ZrO} 2-8 \mathrm{~mol} \% \mathrm{Y}_{2} \mathrm{O}_{3} \mathrm{Ce}-$ ramic Compact Prepared by Citric Acid Gel Route: A Small-Angle Neutron Scattering Investigation, J. Alloy. Compd., 364 (2004) 1, 304-10, doi:10.1016/S0925-8388(03)00613-3

${ }^{45}$ Y. Xiong, J. F. Hu, Z. J. Shen, Dynamic Pore Coalescence in Nanoceramic Consolidated by Two-Step Sintering Procedure, J. Eur. Ceram. Soc., 33 (2013) 11, 2087-92, doi:10.1016/j.jeurceramsoc. 2013.03.015

${ }^{46}$ A. K. Patra, S. Ramanathan, D. Sen, S. Mazumder, SANS Investigation on Evolution of Pore Morphology for Varying Sintering Time in Porous Ceria, Pramana - j. Phys, 63 (2004), 327-31, doi:10.1007/ BF02704993

${ }^{47}$ K. S. W. Sing, D. H. Everett, R. A. W. Haul, L. Moscou, R. A. Pierotti, J. Rouquérol, T. Siemieniewska, Reporting physisorption data for gas/solid systems, Pure Appl Chem (IUPAC), 57 (1985), 603-19, doi:10.1515/iupac.57.0007

${ }^{48}$ H. Q. Ma et al., Influence of Sintering Temperature on the Microstructure and Property of Low-cost Ceramic Proppants Prepared by Adding Purple Sands, IOP Conf. Ser.: Mater. Sci. Eng., 230 (2017)

${ }^{49}$ D. Veljovic, R. Jancic-Hajneman, I. Balac, B. Jokic, S. Putic, R. Petrovic, D. Janackovic, The Effect of the Shape and Size of the Pores on the Mechanical Properties of Porous Hap-Based Bio-ceramics, Ceram. Int., 37 (2011) 2, 471-9, doi:10.1016/j.msec. 2017.03.249

${ }^{50}$ S. J. L. Kang, K. H. Kim, D. N. Yoon, Densification and Shrinkage During Liquid-Phase Sintering, J. Am. Ceram. Soc., 74 (1991) 2, 425-427, doi:10.1111/j.1151-2916.1991.tb06900.x 